\title{
Factors Hindering Use of Standard Weights and Measures along Irish Potato Supply Chain in Njombe Region, Tanzania
}

\author{
Kenneth M. K. Bengesi ${ }^{1}$ \\ 1 Department of Policy Planning and Management, College of Social Sciences and Humanities, Sokoine \\ University of Agriculture, Morogoro, Tanzania \\ Correspondence: Kenneth M. K. Bengesi, Department of Policy Planning and Management, College of Social \\ Sciences and Humanities, Sokoine University of Agriculture, P. O. Box 3035 Chuo Kikuu, Morogoro, Tanzania. \\ E-mail: kenneth.bengesi@suanet.ac.tz
}

Received: April 18, 2018

Accepted: June 5, 2018

Online Published: June 30, 2018

doi:10.5539/ijbm.v13n8p196

URL: https://doi.org/10.5539/ijbm.v13n8p196

\begin{abstract}
Non-compliance with standard weights and measures in agricultural marketing in Tanzania compelled this paper to examined factors hindering use of standard weights and measures along Irish potato supply chain. To address this challenge a cross section research design was used to develop data collection plan and probability sampling was used to draw a representative sample from a sampling frame. The findings revealed that weak enforcement of the regulations governing compliance to standard weights and measures, weak extension services that failed to provide reliable market information to farmers, lack of negotiation skills among smallholder farmers against local brokers / traders coupled with inadequate market infrastructure with appropriate weights and measure facilities provide incentives for local brokers and traders to exploit smallholder farmers. For the sake of fair deals in transactions associated with Irish potato along the supply chain this paper recommends the best practices to ensure responsible business practices among actors.
\end{abstract}

Keywords: standard weight, measures, potato trading, supply chain, Irish potatoes

\section{Introduction}

The main economic activities in Njombe region are agriculture, livestock keeping, forestation and small businesses (Koizumi, 2007; Regional Commissioner RC, 2016). The region has cool climate, fertile soil and reliable rainfall that provide favorable conditions for agriculture development (Mpogole et al., 2013; Namwata et al., 2010). Agriculture in the region has huge potential to create employment, food security, income generation and to further agro processing. The main crops grown in the region include: Irish potatoes, maize, avocados, peas, apples, plums, peaches, tea, coffee and pyrethrum (Masenza, 2015; RC, 2016;).

In terms of economic importance, Irish potato is the leading crop in the region playing a dual role as a food and commercial crop followed by maize (Nyunza \& Mwakaje, 2012). In the 2014/2015 growing season, the total area cultivated Irish potatoes was 45,398.6 hectares of land of which 507,951.84 Metric Tons (MT) of potatoes were harvested (RC, 2016). Most of farmers who cultivate Irish potato in the region are smallholders (Wijnands \& Kamp, 2016) with the farm size ranging from 0.9 to 3 hectares and productivity ranging from 15 tons/ha and 20 tons/ha (Netherlands Enterprise Agency, 2017, Sokoni, 2008, Wolter, 2008a; Wolter, 2008b). The difference in productivity among farmers is contributed by variation in investment, agronomic practices, varieties of Irish potatoes, diseases and pests.

Apart from productivity problems with associated factors, marketing of Irish potatoes suffers from a problem of not using standard weights and measures. According to the Weight and Measure Act (Cap 340) a standard weight for potatoes is a single package that does not exceed 100kg (ECi Africa \& DAI-PESA, 2004). Traders opt to over package their produce in large bags famous known in Kiswahili as "lumbesa" in order to maximize profit on expense of averting the Crop Cess Levy paid to the Local Government and transport costs which are both charged per bag with an assumption that each bag has a standard weight of 100kg (Rural Livelihood Development Company RLDC, 2013). The problem of not using standards weights and measures for agricultural produce started in the early eighties when the government of Tanzania adopted trade liberalization policies (TCCIA, 2013a). It was at this time when the private sector was given legal freedom to operate business with minimum regulations. 
With the understanding of the implication for non-compliance with the regulations governing standard weights and measures the government has taken several steps such as to strengthen human resources to the Weight and Measure Authority (WMA) by employing more staff, increasing budgets to the WMA, strengthened collaboration between the WMA and other law enforcers such as Police Force in their operations (RLDC, 2013; TCCIA, 2013b; RLDC, 2012). Despite the effort by the government to address the problem of non-compliance with the standard weights and measures regulations, the response among traders is mixed (Bengesi \& Rogers, 2016). There are actors along the supply chain who claim that traders have complied with the regulations since the packaging materials have changed from the previous practice (lumbesa) and others are claiming the current practice still does not comply with the requirement of the regulations (Agricultural Council of Tanzania ACT, 2018).

In view of this debate, this paper responds to a series of empirical questions such as; who are the key actors along the Irish potato supply chain responsible for the malpractices of not using standard weights and measures? What are the current practices on the use of standard weights and measures along Irish potato supply chain in the study area? What are the challenges limiting the use of standard weights and measures along the Irish potato supply chain? And finally, what are the possible solutions to ensure responsible business practices along the Irish potato supply chain? The rest of the paper is structured with three sections; first the literature review which gives an overview of the global and local Irish potato production and marketing and the existing regulatory framework. Secondly, the research methodology that highlights the research design, sampling procedure and the data analysis procedure. The last section is on results and discussion, which presents the key findings and their implication; areas for further studies and draw final recommendations on the possible ways to address the identified challenges.

\section{Literature Review}

\subsection{Market Practices of Irish Potatoes in Tanzania}

The market practices of Irish potatoes in Tanzania have been documented by Nyange (1993) and Kabungo (2008). According to Nyange (1993), the round potato market channel consists of producers, truckers, wholesalers, retailers, hawkers, and consumers. However, Kabungo (2008) identifies six key players in the Irish potato supply chain; farmers/producers, village traders, urban brokers, wholesalers, urban retailers, and consumers and processors.

The literature shows that about $82 \%$ of Irish potato farmers sell the produce to traders direct from the farm (Bengesi \& Abdalla, 2018; Mpogole et al., 2013; Nyunza \& Mwakaje, 2012). Very few transport their crop to different places outside their farm villages to neighbouring countries, and local cities like Dar es Salaam, and other regions (Namwata et al.,, 2010). However, most flows of food crops including round potatoes within Tanzania are toward Dar es Salaam because of growth in population relative to the rest of the country (Gabagambi, 2003). Major customers are wholesalers, truckers, individual consumers and retailers (Wijnands \& Kamp, 2016). This means that many farmers sell the crop to traders who then transport to different places within and outside the country like Dar es Salaam and other urban centres in Tanzania, Malawi, Zambia, and DRC.

According to TCCIA (2013a), round potato farmers usually harvest their produce only when a buyer is available and has sent packaging bags. Usually village brokers or traders approach farmers, in some cases the vice versa is true after which a price deal is set. Often, the produce is sold at farm-gate and on a cash basis, very few, supposedly wealthy farmers, directly transport and wholesale their produce to urban markets (Kabungo, 2008). Also, some farmers sell their produce by roadside or to the weekly village markets or to the village retailers.

Village traders (also called assemblers or collectors) come from the production areas and know the farmers in their areas. Usually they know farmers who have grown round potato and the time they are likely to harvest. These village traders are in contact with transporters, wholesalers and retailers through their mobile phones (Mpogole et al., 2013; Namwata et al., 2010). After identifying farmers willing to sell at an agreed upon price, they make contact with the transporters (travelling traders) or wholesalers on the amount that would be available and the price. According to Kabungo (2008), usually a mark-up is put to the price they mention to transporters or wholesalers or urban traders/brokers. The middlemen or local traders buy Irish potato from farmers or village traders and then transport and sell them to wholesalers and urban retailers. In Dar es Salaam, local traders can sell their truckload of round potatoes to one market agent and market agent sells to retailers from different markets.

While it is compelling to believe that operating in an open market economy could have advantaged the smallholder farmers to sell their produce at relative good price given the fact that they operate at farm gate price with minimum extra costs apart from production (Bengesi \& Le Roux, 2014a; Bengesi, 2013). This has not been 
the case, farmers continued suffering from use of unauthorised weights and measures of which in most cases farmers are losers due to over packaging of Irish potatoes (ECi Africa \& DAI-PESA, 2004; Mpogole et al., 2013). In view of the fact that there are several actors along the Irish potato supply chain; this leads to an interesting questing on.

Question 1: Who are the key actors along Irish potato supply chain responsible for the malpractices of not using standard weights and measures?

Understanding of the key actors along the Irish potato supply chain responsible for the malpractices of not using the standard weights and measures opens up for the solution to address the outstanding problem of farmers exploitation.

\subsection{Compliance with Regulations among Stakeholders}

There are several Acts and regulations guiding packaging and transportation of agricultural products. The Weight and Measures Act (Cap 340) provides guidelines for standard weight of various crops. However, for unstated crops like Irish potato the Act provides a maximum weight limit of not more than $100 \mathrm{Kg}$ per package. The Weights and Measures Agency (WMA) is an Executive Agency, responsible for fair trade transactions through certification of weights and measures. It is the sole agency in Tanzania for enforcing the Weights and Measures Act (Cap 340).

The WMA ensures that all traders comply with the requirements of the Weights and Measures Act (Cap 340) in order to protect producers and consumers against malpractices. Thus the Mandate of WMA is to verify and re-verify all weights, measures, weighing or measuring instruments used or intended to be used for trade in Tanzania Mainland. The roles of WMA as stipulated under the Weights and Measures Act (Cap 340), and the Executive Agencies Act (Cap 245) are to: protect consumers in trade, health, safety and environment in relation to weights and measures; Protect society from the consequences of false measurements in public and private transactions, and Control pre-packaging of products to mention a few.

In the context of existence of the WMA one would expect fair deals between producers (farmers) and the local brokers / trader since they are regulated by the WMA. However, in the real sense the problem of non-compliance with weights and measures still persists. With this understand the government took several initiatives such as to increase budget and employ more staff to WMA (TCCIA, 2013b). These measures were taken to increase effectiveness of the WMA to discharge its mandated responsibilities including reinforcing the compliance with the standard weights and measures.

Despite these efforts the results on compliance with the standard weights and measures is still mixed (Bengesi \& Rogers, 2016). While the proponents argue that there is compliance among traders on the use of the standard weights and measures, the opponents argue that the problem of non compliance still exist although there is a minor shift on the modality of packaging. This controversy raises an important question on:

Question 2: What are the current practices on the use of standard weights and measures along the potato supply chain?

The WMA work in collaboration with the regional governments and other actors in the Irish potatoes supply chain, to implement the Weights and Measures Act (Cap 340) and subsidiary regulations to protect farmers as well as enabling the LGAs to collect due crop cess levy (RLDC, 2012). For example, the Agency in collaboration with the Regional and Local Government Authorities organizes sensitization workshop and seminars to farmers and traders, where relevant sections of the W\&M Act (Cap 340) are presented. Even though several attempts have been made by the WMA and other actors the use of unauthorized weight and measures is still prevalent to date. This situation raises an empirical question on

Question 3: What are the challenges limiting the use of authorized weights and measures along the Irish potatoes supply chain?

Understanding the challenges limiting the use of authorized weights and measures is one thing, finding a proper solution is another. In this context the most important question to answer is

Question 4: What could be the possible solutions to ensure responsible business practices along the Irish potato supply chain?

Responsible business practices ensure fair deals to all actors along the supply chain from farmers to consumers. 


\section{Methodology}

\subsection{Research Design and Sampling Procedure}

This study was carried out in Njombe region specifically in Njombe Town Council and Wanging'ombe District Council where most of Irish potato farming is practiced in the region (Mpogole et al., 2013). The research adopted cross sectional research design in which data was collected at one point in time. According to the Zikmund (2003) cross sectional research designs are used for population-based surveys to assess the characteristics of interest from representative samples. These studies can usually be conducted relatively faster and are inexpensive compared to other designs like longitudinal studies.

A sampling frame was developed from a list of smallholder farmers obtained from each village office, and lists of traders and middlemen, which were obtained from Offices of Village Executive Officers (VEOs) in the study villages. Thereafter, a simple random sampling technique was used to draw a representative sample for smallholder farmers, middlemen, transporters, and potato traders. According to Cooper and Schindler (2011) random sampling is considered as a fair way of selecting a sample from a given population since every member is given equal opportunities of being selected.

\subsection{Data Collection}

A combination of methods were used during data collection; field survey was used to collect primary data coupled with the review of relevant documents for secondary data that was adopted to generate relevant information to the study. The desk review encompassed review of relevant documents such as Weight and Measure Act (Cap 340) and its amendments, fee and levy bylaws for Wanging'ombe Local Government Authority, and various reports related to the assignment. The essence of reviewing these documents was to learn from the legal and regulatory requirement and compare with the current practice to ascertain if the regulations and the national laws on weight and measures are adhered to.

\subsection{Data Analysis}

Data analysis and interpretation followed right after data collection. Descriptive statistics such as frequencies were used to indicate the distribution of characteristics of interest. Direct observation was used to identify current measurements used to sell potato compared to the standard measure as per regulations. To identify factors limiting use of standard measure researchers interviewed farmers, traders, brokers, Weight and Measure Agency (WMA) and Local Government Authority (LGA) officers.

\section{Results and Discussion}

This paper answers three key questions; who are the key actors along the Irish potatoes supply chain responsible for the malpractices of not using the standard weights and measures? What are the current practices on the use of standard weights and measures along the Irish potato supply chain in the study area? What are the challenges limiting the use of standard weights and measures along the Irish potato supply chain? And finally, what are the possible solutions to ensure responsible business practices along the Irish potato supply chain? To ascertain the distribution of characteristics of interests among respondents before embarking on the key results the next section presents the social economic characteristics of the respondents.

\subsection{Socio-economic Characteristics}

The social economic characteristics were examined to establish the distribution of characteristics of interest. The results presented in table 1 revealed that there were 41.1 percent and 22.8 percent of women for Njombe TC and Wnaging'ombe DC, respectively. The findings revealed that in Wanging'ombe DC few women were represented in the study compared to men as reversed to Njombe TC. The reasons for this could be the possibility that Irish potato is crop that play a dual role i.e. food and cash crop at the same time. Given the fact that Wanging'ombe DC is more rural compared to Njombe TC there is a possibility of cultural influence of male dominance in rural areas (Wanging'ombe DC) especially when it comes to monetary decisions. This argument is in line with that given by Ringo et al (2018) who observed that in African traditions specifically rural areas where cultural influence is still dominant women hardly make monetary decisions in the absence of men. 
Table 1. Socio-economic characteristics of the respondents

\begin{tabular}{lllll}
\hline & Njombe TC & & \multicolumn{2}{l}{ Wanging'ombe DC } \\
Socio-economic attributes & Frequency & Percentage & Frequency & Percentage \\
\hline Sex & & & & \\
Male & 86 & 58.9 & 36 & 77.2 \\
Female & 60 & 41.1 & $\mathbf{1 5 8}$ & 22.8 \\
TOTAL & $\mathbf{1 4 6}$ & $\mathbf{1 0 0 . 0}$ & & 100.0 \\
Age of respondent & & & 33 & 20.9 \\
18-29 years & 28 & 19.1 & 52 & 32.9 \\
$30-44$ years & 55 & 37.7 & 63 & 39.9 \\
$45-59$ years & 48 & 32.9 & 10 & 6.3 \\
60 and above & 15 & 10.3 & $\mathbf{1 5 8}$ & $\mathbf{1 0 0 . 0}$ \\
TOTAL & $\mathbf{1 4 6}$ & $\mathbf{1 0 0 . 0}$ & & 11.4 \\
Level of education & & & 18 & 75.3 \\
No formal education & 12 & 8.2 & 12 & 7.6 \\
Primary education & 108 & 74.0 & 9 & 5.7 \\
Secondary education & 24 & 16.4 & $\mathbf{1 5 8}$ & $\mathbf{1 0 0 . 0}$ \\
Above secondary education & 2 & 1.4 & & \\
TOTAL & $\mathbf{1 4 6}$ & $\mathbf{1 0 0 . 0}$ & 132 & 83.5 \\
Marital status & & & 16 & 10.1 \\
Married & 123 & 84.2 & 10 & 6.3 \\
Single & 8 & 5.5 & $\mathbf{1 5 8}$ & $\mathbf{1 0 0 . 0}$ \\
Separated/widowed & 15 & 10.3 & & \\
TOTAL & $\mathbf{1 4 6}$ & $\mathbf{1 0 0 . 0}$ & & \\
\hline
\end{tabular}

With regards to the age of farmers, the findings in table 1 shows that the majority of farmers were at the age of between 30 and 59 years and ranged between 32.9 percent and 39.9 percent for both Councils, with the few farmers at the age of below 30 years $(19.1 \%-20.9 \%)$ and above 60 years $(6.3 \%-10.3 \%)$. The findings may imply that the age between 30 and 59 is the active age group to engage in agriculture. However, on the other hand the low participation of young generation in agriculture may suggest the aging problem in agriculture in a near future. This may have implication in the sustainability of the farming activity in future if measures to encourage young generation to engage in agriculture are not taken.

Looking at the level of education the findings show that for Njombe TC and Wanging'ombe DC about 74 percent and 75.3 percent of farmers, respectively were primary school leavers and about 8.2 percent and 11.4 percent had no formal education for Njombe TC and Wanging'ombe DC, respectively. The findings suggest that since the majority own basic education they can easily adopt new agricultural technologies, improve productivity and use standard weights and measures in transactions. However, according to Bengesi and Le Roux (2014b) the level of education may limit networking to other regions where they can solicit market information. This argument is based on the fact that primary education is normally offered within the same village where these farmers are born. This may suggest that the networking, which is essential for access to market information and penetration to market is limited within the boundaries of the village. This may explain why farmers continue experiencing exploitation from traders and local brokers because the brokers and traders have broadened their network beyond the village boundaries and are well informed about the market dynamics compared to farmers.

In view of the marital status the findings in table 1 indicate that the majority of farmers taking part in farming Irish potato for Njombe TC (84\%) and Wanging'ombe DC $(83.5 \%)$ are married. This finding suggest that married farmers have more responsibilities to take care about the family needs, which could drive them to engage in economic activities to generate adequate money to carter for the growing needs of the family. Given the fact that Irish potato is one of the cash crop in the study area possibly this could explain why the majority of married farmers are engaged in farming Irish potato.

\subsection{Key Actors along Irish Potato Supply Chain}

In response to the first research question this paper identified key actors along the Irish potato supply chain in the study area. The findings in table 2 revealed that there are several actors positioned in different nodes along the Irish potato supply chain. Among the most prominent key actors includes smallholder farmers who are responsible for farming and selling of potatoes mainly at farm gate price, local brokers / middlemen who link 
bulk buyers/traders with farmers and are responsible to buy potatoes directly from farmers and sell in bulk to buyers from different parts of Tanzania and outside the country, transporters are responsible to haul produce from farm/production centers to different market outlets within and outside Njombe region, brokers in the vegetable markets receive Irish potato in bulk and sell to a wider network of retailers in the retail outlets, and finally to consumers.

Table 2. Roles and responsibilities of the key actors in each council

\begin{tabular}{|c|c|c|c|c|}
\hline \multirow[b]{2}{*}{ S/No. } & \multirow[b]{2}{*}{ Key actors } & \multicolumn{2}{|c|}{ Number of respondents } & \multirow[b]{2}{*}{ Roles and responsibilities } \\
\hline & & $\begin{array}{c}\text { Njombe } \\
\text { TC }\end{array}$ & Wanging'ombe DC & \\
\hline 1 & Smallholder Famers & 146 & 158 & $\begin{array}{l}\text { - Farming of Irish potatoes } \\
\text { - Sell Irish potato at gate farm price } \\
\text { - Price takers / lack negotiation skills }\end{array}$ \\
\hline \multirow[t]{2}{*}{2} & $\begin{array}{l}\text { Brokers/Middlemen } \\
-\quad \text { Local brokers }\end{array}$ & 18 & 21 & $\begin{array}{l}\text { - Buy from farmers at lower price } \\
\text { - Hold market information } \\
\text { - Have linkage with wholesalers }\end{array}$ \\
\hline & $\begin{array}{l}\text { - } \quad \text { Brokers } \\
\text { vegetable markets }\end{array}$ & 15 & - & $\begin{array}{l}\text { - Buy from local brokers } \\
\text { - Hold network of buyers from } \\
\text { retail outlets }\end{array}$ \\
\hline 3 & Transporters/haulers & 28 & 16 & $\begin{array}{l}\text { - Haul Irish potatoes from farm to } \\
\text { collection centres } \\
\text { - Haul Irish potatoes from collection } \\
\text { centres to markets }\end{array}$ \\
\hline 4 & Retailers & 30 & 18 & $\begin{array}{l}\text { - Buy Irish potatoes from wholesalers } \\
\text { - Sell Irish potatoes to consumers } \\
\text { - Use }\end{array}$ \\
\hline 5 & Input suppliers & 20 & 8 & - Supply inputs to farmers \\
\hline \multirow[t]{3}{*}{6} & Regulatory authorities & & & \\
\hline & WMA & 5 & - & $\begin{array}{l}\text { - Enforcement of regulation governing } \\
\text { weights and measures. } \\
\text { - Protect consumers' rights. } \\
\text { - Verify measurement scales. } \\
\text { - Create awareness on standard weights } \\
\quad \text { and measures }\end{array}$ \\
\hline & LGA & 26 & 12 & $\begin{array}{l}\text { - Provision of extension services to } \\
\text { farmers. } \\
\text { - Collection of Cess levy } \\
\text { - Developing bylaws governing the } \\
\text { business environment in the district }\end{array}$ \\
\hline
\end{tabular}

Note. $\mathrm{TC}=$ Town Council; $\mathrm{DC}=$ District Council; $\mathrm{WMA}=$ Weight and Measure Authority; $\mathrm{LGA}=$ Local Government Authorities.

In view of the above, it is clear that brokers appear in two different nodes between buyers and farmers and these are generally local brokers who reside in the same or nearby villages and are well known to farmers. The second category of brokers are those who are stationed in fresh vegetable market located in other regions and normally they are responsible to receive produce in bulk and distribute to retail outlets. The haulers or transporters were observed to facilitate transportation of potatoes from one place to another i.e. from farm to collection centers, collection centers to Njombe Town, then from Njombe to other regions or outside the country.

On the other hands, there is a regulatory framework composed of Weight and Measure Agency (WMA), and Local Government Authority (LGA) to mention a few. The WMA is responsible for enforcement of the regulations governing weight and measures to protect consumers' rights, verify measurement scales, create awareness on compliance to standard measures. The Agency also is responsible to conduct annual inspection of weighing scales in various business enterprises to ensure consistency and penalise individuals who tampered 
with the weighing scales and organize ad hoc inspection through roadblocks to inspect trucks hauling potatoes if the volume of potato is according to the legal standard of not more than $100 \mathrm{Kg}$ per bag.

However, the WMA lack capacity in terms of manpower to deliver effective services since they do not have officers at the district level and they rely only on the regional office, which is usually understaffed. Taking an example of Njombe Regional Office, has only 3 officers who are responsible for the whole region, with six districts. The limited number of staff at the region office and failure of WMA to hold offices at the district level hampers its efficiency in service delivery. To improve efficiency of service delivery including enforcement of regulations governing weight and measures; the WMA should consider increasing the number of staff at the regional office and possibly establishing a supporting desk at the LGA.

With regards to the potato trade, the LGA is responsible to create supportive environment for farmers to optimize production of potatoes through provision of agricultural extension services to farmers. In the study area each Ward had an Agricultural Extension Officer, who serves several villages within a given Ward to provide agricultural technical support to farmers. However, the efficiency was observed to be constrained by the meager resources allocated to support agricultural development, which does not support movement of officers to reach farmers in diverse villages. This situation has constrained extension service delivery system and has opened up a parallel line of local brokers to fill the gap by providing false market information to farmers, which subsequently has led to farmers' exploitation.

Moreover, the LGA also observe the conduct of potato business in their jurisdiction area given the fact that the crop is the major source of own source income. According to both Local authorities (Njombe Town Council and Wanging'ombe District Council), potato account for about $45 \%$ and over $80 \%$ of their own source income collected as a Cess Levy, respectively. The LGA after collection of cess levy pays back $20 \%$ of collected tax to each Ward that is devoted to support development activities in respective villages based on the priority areas, which is not necessarily agriculture.

In view of the fact that agriculture is the major contributor to the own source income one would expect the sector to be allocated with large proportion of budget from the local authority to promote agriculture development and sustain LGA cash flow. On contrary for both councils it was clear that large proportion of the budget was directed to the so called priority sectors such as health and education, and agriculture received only the least budget allocation of less than $5 \%$ of the total collection from own source income. This is contrary to the LGA regulations that requires at least $20 \%$ from own source be allocated for agriculture development. The findings suggest that LGA are not getting their priority right since investment are intensified on productive assets rather than liabilities to ensure sustainability of cash flow. However, this is not to say that education and health sectors are liabilities but rather the LGA should strike a balance to support productive sectors so that they are able to maximize income and support other sectors.

\subsection{Current Practices on Use of Weight and Measures}

In the course of research it was necessary to observe and identify types of measurement used in selling potato at different points along the supply chain. As mentioned earlier along the potato supply chain there are several actors positioned on different nodes. The measurements used by different actors were observed to be different from one node to another. For example, between farmers and the middle men / local brokers the dominant measurement used were "debe" (20 liter platic container), which are plastic containers and bags of different sizes but normally with carrying capacity beyond the recommended weight of not more than $100 \mathrm{~kg}$ (ECi Africa and DAI-PESA, 2004; Bengesi \& Rogers, 2016).

The implication of using bags with carrying capacity beyond 100kg is reflected in the revenue loss of the LGA and transport cost for transport owners, which are normally changed per bag of Irish potato. For example, taking the average standard weight of an Irish potato to be $100 \mathrm{~kg}$, if the common practices is to pack between $130 \mathrm{~kg}$ and $140 \mathrm{~kg}$ of Irish potatoes this implies that the Local Government loses between 30 and 40 percent of revenue loss for each bag of Irish potato and this loss translate the same to the transport charges and farmers' income losses.

The retail outlets were observed to use mixed weight and measures of which some used 20 or 10 Liters plastic containers known as "debe" or "ndoo" in Kiswahili, and sadoline (3 liters plastic containers) and others used standard weighing scale. While it is a common practice to use unauthorized weight and measures in potato trade in the study area, it is evident that those containers were not meant for measuring weight but rather were meant for measuring liquid products such as cooking oil, paints, chemicals and other products. Using such facilities to measure weight is a gross violation of the Weight and Measure Act (Cap 340) that protect the rights of consumers and does not ensure fair deal between buyers and sellers, as it should be. Use of 10 and 20 liters 
container, which are normally assumed to weight 10 and $20 \mathrm{~kg}$, respectively consumers loses up to $5 \mathrm{~kg}$ for 20 liters container and $2.5 \mathrm{~kg}$ for a 10 liters container. This loss suggest that consumers pay 25 percent more to traders for not using standard weighing scales.

Table 3. Market points and the applicable weight and measures

\begin{tabular}{|c|c|c|}
\hline S/No. & Market point & Common Weight \& Measure \\
\hline 1 & Farmers and middlemen & $\begin{array}{l}\text { - } \quad \text { Bags with carrying capacity beyond } 100 \mathrm{~kg} \\
\text { - } \quad \text { Plastic containers (i.e. } 3 \text { liters, } 10 \text { liters, } 20 \text { liters) }\end{array}$ \\
\hline 2 & Middlemen & - $\quad$ Bags beyond recommended weight $100 \mathrm{~kg}$ \\
\hline 3 & Common markets & $\begin{array}{ll}\text { - } & \text { Plastic containers (i.e. } 3 \text { liters, } 10 \text { liters, } 20 \text { liters) } \\
\text { - } & \text { Standard weighting and Measures }\end{array}$ \\
\hline 4 & Supermarket \& Supermarkets & - $\quad$ Standard weighting scale \\
\hline
\end{tabular}

\subsection{Factors Hindering the Use of Standard Weight in Potatoes Trading}

The paper identified several factors existing along Irish potato supply chain. Some of these factors are responsible to accelerate the problem of non-compliance with the standard weight and measures. For example, the Weight and Measure Act (Cap 340) provides standard weight limit of $100 \mathrm{~kg}$ per bag for potato but the trading practice is based on volume such as plastic containers of 10 and $20 \mathrm{~kg}$ and bags of uncontrolled size that normally weight up to $140 \mathrm{~kg}$. This may suggest weak institutional capacity and inadequate number of personnel in the WMA to reinforce effectively the Weight and Measure Act (Cap 340). Consequently, this situation has opened up for middlemen and traders to continue exploiting smallholder farmers by using bags of carrying capacity beyond $100 \mathrm{~kg}$.

Inadequate market infrastructure / centers and facilities to cater for potatoes trading is another challenge that restricts traders to have direct link with farmers, coupled with the weak extension services observed in the study area created a dependence syndrome for farmers to rely on market information from middlemen / local brokers. This situation has opened up for the local brokers to bridge the gap and take advantage to exploit smallholder farmers who suffer from the market information asymmetry. Failure of farmers to obtain the right market information put them on a disadvantage side and limits the ability of farmers to negotiate with the local brokers / middlemen and to make the right decision on the use of standard weight and measures and the price of their produce.

Variation of tax rates especially the cess levy among LGAs within the same region is another challenge that created unfair ground for traders to operate smoothly but also account to the loss of revenue among district councils charging lower rates. During the study it was evident that Njombe TC charged 5 percent of Cess Levy while Wanging'ombe DC charged only 3 percent of cess levy to Irish potato traders. While it was beyond the scope of this paper to establish the extent of losses realized as a result of variations in tax rates among the councils, the paper recommends that it could be interesting in future to examine such a differential loss. This paper is in the opinion that under the good tax management the cess levy collected from agricultural produce could curb to a large extent budget deficit currently experienced in the LGAs. This is especially applicable to most LGAs located in agricultural high potential areas like Njombe region (Bengesi \& Rogers, 2016). Unfortunately, most LGAs do not consider agriculture as a priority sector despite the significant contribution it makes to the own source income. This can be explained by low allocation of the budget to agricultural sector, which has enormously affected the development of extension services in the region.

\subsection{Proposed Solutions to Address the Identified Challenges}

Based on findings, this paper draws several recommendations on the way forward. Among the recommendations to address the identified challenges include awareness creation, to stakeholders along the supply chain. Awareness creation will continue to stimulate and motivate actors in the potato trade to demand the use of standard weight and measures. This is based on the fact that smallholder farmers and consumers are not aware how much loss they incur for selling and or buying of Irish potatoes from unauthorized weight and measures. Similarly, the LGA and the transporters who charge cess levy and transport costs per bag, respectively both are not aware of how much loss go unaccounted by charging on volume instead of standard weight. This paper is in the opinion that once such stakeholders are informed on the actual loss they make in the current practices they are likely to change their current practices and force the local brokers and traders to abide by responsible 
business practices that ensure equal benefit sharing along the supply chain.

Another area for intervention is to create common collection centers with robust market infrastructures equipped with standard weights and measures facilities. The common collection centers will create a meeting platform between farmers and traders and eliminate the exploitation of farmers by middlemen since traders will be able to come to the market and have direct contact with farmers. The common market centers should also have a wing for market information desks to provide market and agronomic information to farmers. This will minimize monopoly of information to brokers/middlemen, which is used as weapon to exploit farmers.

For the sake of controlling over packaging of potatoes the paper suggests two options: the first option should be to introduce a common / standard package bag for potato which will be adopted countrywide. This strategy should be taken as a short-term measure during this stage where there is low capacity for WMA to reinforce the regulation and there are no standard weighting scales to farmers. The second option should be to adhere to the existing regulation that requires potatoes to be weighted through standard weights and not volumes as it is currently practiced. The second strategy is more practical once the common collection centers are established and are well equipped with the standard weighting facilities.

In view of the fact that farmers lack negotiation skills on prices of their produce this paper considers it is higher time to build their capacity to withstand pressure from middlemen and brokers. Coupled with improved accessibility of farmers to the market information through common collection centers it is likely to strengthen their ability to negotiate price of their produce and realize the economic value of their products. However, it is higher time for further research on power dynamics among actors along the Irish potato supply chain to be able to identify the most powerful actors who are responsible to influence malpractices for not using standard weights and weights.

To address the challenges of ineffectiveness of the WMA this paper suggest that the WMA should work in collaboration with the LGAs to supervise and facilitate law enforcement. Also they can launch a joint effort to mobilize resources for the development and implementation of the bylaws. In long run the number of WMA staff should be increased to reflect the magnitude of the responsibility they hold. The current number of staff is inadequate to ensure effectiveness of service delivery.

In view of the fact that most LGAs suffer budget deficit every year and agriculture being one of the key sector in most agricultural high potential areas accounting for a substantial contribution to the own source income; the LGAs should consider agriculture as a priority sector. This should be done by increasing the budget allocation to the sector to be able to strengthen extension services. Also under good tax management i.e. harmonization of tax rates for cess levy may create favorable environment for traders and build spirit of voluntary compliance with tax payment that subsequently increase LGA income from own source.

\section{References}

Agricultural Council of Tanzania ACT (2018). Multiple Regulations in the Agricultural Sector. Policy Brief, 1-4. Retrieved from: http://actanzania.or.tz/publication/multiple-regulations-agricultural-sector/

Bengesi, K. M. K. (2013). Strategic Entrepreneurial Response of Small and Medium Enterprises. PhD. University of Pretoria.

Bengesi, K. M. K., \& Abdalla, J. O. (2018). Forces Driving Purchase Behavior of Tourism Hotels Along Tourist-Agricultural Supply Chain in Zanzibar. International Journal of Marketing Studies, 10(2)36-46. http://doi.org/10.5539/ijms.v10n2p36

Bengesi, K. M. K., \& Rogers, A. (2016). Non compliance to Standard Weights and Measures in Irish Potato trade in Tanzania. Unpublished Report Presented During the MVIWATA Annual Conference held in Morogoro Municipal on $8^{\text {th }}-12^{\text {th }}$ August 2016.

Bengesi, K. M. K., \& Le Roux, I. (2014a). Strategic Entrepreneurial Response of Small and Medium Entreprises in Developing Economies. International Journal of Business and Management, 9(2), 153-165. https://doi.org/10.5539/ijbm.v9n2p153

Bengesi, K. M. K., \& Le Roux, I. (2014b). The Influence of Dimensions of Networking Capability in Small and Medium Enterprise Performance. International Journal of Business and Social Science, 5(2), 189-200.

Cooper, D. R., \& Schindler, P. S. (2011). Business Research Methods (11th ed.). New York: McGraw-Hill.

ECi Africa \& DAI-PESA. (2004). A Study on Weight and Measures Practices in Tanzania. Retrieved from http://www.best-dialogue.org/wp-content/uploads/TCCIA-2004-05Tanzania-Weights-and-Measures-Practic es-ECIDAI.pdf?x82837 
Gabagambi, D. M. (2003). Road Infrastructure Investment and its Impact on Agricultural Productivity and Equity in Tanzania. Beuren, Hohenheim.

Kabungo, C. V. D. (2008). Evaluation of Irish Potato Production and Marketing Performance: A Case Study of Mbeya Rural District. Unpublished Dissertation for Award of MSc Degree at Sokoine University of Agriculture, Morogoro, Tanzania.

Koizumi, M. (2007). Comparative study of farming systems in South-Western Tanzania: Agrarian adaptation in a social-historical perspective. African Study Monographs, 34, 3-20.

Masenza, A. J. (2015). A Brief Report Presented to the Development Partners Group During their Visit to Iringa Region from $25^{\text {th }}$ to $27^{\text {th }} \quad$ February, 2015. Retrieved from https://www.google.co.tz/url?sa=t\&rct=j\&q=\&esrc=s\&source=web\&cd=1\&ved=0ahUKEwitwai9sLnaAhV pCZoKHSwUDMIQFgglMAA\&url=http $\% 3 \mathrm{~A} \% 2 \mathrm{~F} \% 2 \mathrm{Fwww} . t z d p g . o r . t z \% 2 F f i l e a d m i n \% 2 F d o c u m e n t s \% 2 \mathrm{Fd}$ pg_internal\%2Fdpg_main\%2FDPG_Main_2015\%2FDPG_Main_March_2015\%2FREGIOANAL_BRIEF_ TO_to_DPG_on_25_to_27_02_2015_-_edited_24._02_2015.doc\&usg=AOvVaw1E2wAjV35hbm7Czegv $\mathrm{XxzZ}$

Mpogole, H., Mlambiti, M. E., \& Kadigi, M. J. (2013). Round Potato Production in Southern Highlands of Tanzania: Are Smallholder Farmers Becoming Commercial? A Paper Presented at REPOA's $18^{\text {th }}$ Annual Research Workshop held at the Kunduchi Beach Hotel, Dar es salaam, Tanzania, April 3-4, 2013. Retrieved from http://www.repoa.or.tz/documents storage/GD4.pdf

Namwata, B. M. L., Lwelamira, J., \& Mzirai, O. B. (2010). Adoption of improved agricultural technologies for Irish potatoes (Solanum tuberosum) among farmers in Mbeya Rural District, Tanzania: A case of Ilungu ward. Journal of Animal \& Plant Sciences, 8(1), 927-935.

Netherlands Enterprise Agency. (2017). Seed potatoes Tanzania. Retrieved from https:/www.rvo.nl/sites/default/files/2017/05/Seed_potatoes_tanzania_quick_scan.pdf

Nyange, D. A. (1993). Economics of vegetable marketing in Tanzania: A case study of Arumeru District. Unpublished Dissertation for Award of MSc Degree at Cornell University.

Nyunza, G., \& Mwakaje, A. E. (2012). Analysis of round potato marketing in Tanzania: The case of Rungwe District, Tanzania. International Journal of Business and Social Science, 3(23), 8-15.

Regional Commissioner (RC). (2016). A brief Report on Potato Production in Njombe Regional. Retrieved from https://www.rvo.nl/sites/default/files/2017/05/Aardappelproductierapport_2016_regio_njombe.pdf

Ringo, J., Bengesi, K.M.K, \& Mbago, M. (2017). Access and Challenges of Health Facilities amongst Agro-pastoralist Communities in Handeni District, Tanzania. Journal of Population and Social Studies, 26(1), 53-67. https://doi.org/10.25133/JPSSv26n1.005

Rural Livelihood Development Company RLDC. (2012). Assessment of Standardization, Weights and Measures and their Implication in Transaction Costs in the Agricultural Value Chains. Final Report, February. Retrieved from https://agriknowledge.org/downloads/c821gj795

Rural Livelihood Development Company RLDC. (2013). Assessment of Adherence to Recommended Weights and Measures in Grain Value Chain Implication on Transaction Costs. Tanzania Markets PAN. Policies that work for Markets.

Sokoni, C. H. (2008). Commercialisation of Smallholder Production in Tanzania: Implications to sustainable resource management. The Geographical Journal, 174(2), 158-161. https://doi.org/10.1111/j.1475-4959.2008.00287.x

TCCIA (2013a). Iringa for the National Enforcement of Weight and Measures Technology and Procedures Project.

TCCIA (2013b). Follow-Up and Evaluation of the Weights and Measures Actof 1982 in the Pilloted Regions of Iringa and Njomber from http://www.best-dialogue.org/wp-content/uploads/TCCIA_BFR_-Iringa_Policy_Action_2013_11.pdf?x828 37

Wijnands, F., \& Kamp, J. (2016). An overview from an Outsider Perspective: Potato Crop in Tanzania. Retrieved from https://nabc.nl/uploads/content/files/1330\%20Opportunities\%20potato\%20industry.pdf

Wolter, D. (2008a). Tanzania - Why a Potential Food Exporter is still Importing Food. OECD Development Centre, Paris. 
Wolter, D. (2008b). Tanzania - The challenge of moving from subsistence to profit. OECD Development Centre, Paris.

Zikmund, W. G. (2003). Business Research Methods (7th ed.). Thomson South Western, USA.

\section{Copyrights}

Copyright for this article is retained by the author(s), with first publication rights granted to the journal.

This is an open-access article distributed under the terms and conditions of the Creative Commons Attribution license (http://creativecommons.org/licenses/by/4.0/). 